\section{DELIK PENODAAN AGAMA DI TINJAU DARI SUDUT PANDANG HUKUM PIDANA DI INDONESIA ${ }^{1}$ \\ Oleh : Randy A. Adare ${ }^{2}$}

\section{ABSTRAK}

Jaminan kebebasan kehidupan beragama di Indonesia sebenarnya cukup kuat. Namun, keindahan aturan-aturan normatif tidak serta merta indah pula dalam kenyataannya. Banyak sekali warga Negara Indonesia yang merasa dikekang kebebasannya dalam memeluk agama dan berkeyakinan. Kerukunan hidup beragama termasuk faktor penting untuk terciptanya stabilitas dan ketahanan nasional, maka merupakan pra-syarat mutlak dalam pelaksanaan dan keberlangsungan pembangunan. Kerukunan hidup beragama terdiri dari kerukunan intern umat beragama, antar umat beragama, dan umat bergama dengan pemerintah. Kerukunan intern umat beragama masih sering mendapat gangguan dengan adanya perbedaan aliran-aliran atau paham-paham yang dibesar-besarkan, atau terjadinya perselisihan antara pimpinan dengan membawa-bawa umat. Negara Indonesia yang multi agama, multi etnik dan multi ras dapat terhindar dari hal-hal menghancurkan khususnya konflik-konflik antar umat beragama. Dengan demikian sifat perjuangan dalam mewujudkan tegaknya HAM di Indonesia itu tidak bisa dilihat sebagai pertentangan yang hanya mewakili kepentingan suatu golongan tertentu saja, melaikan menyangkut kepentingan bangsa Indonesia secara utuh. Dalam rangka memberikan perlindungan hukum atas adanya kepentingan hukum bagi setiap warga negara tersebut, maka ketentuan tentang delik penodaan terhadap agama diatur dalam RUU KUHP. Oleh karena itu perangkat peraturan perundang-undangan yang mengatur

\footnotetext{
${ }^{1}$ Artikel skripsi.

${ }^{2}$ NIM: 090711043.
}

mengenai delik agama harus direkonstruksi dan di reevaluasi kembali sehingga delik agama dapat ditangani secara profesional dan proporsional oleh aparat penegak hukum.

Kata kunci: penodaan agama

\section{A. PENDAHULUAN}

Indonesia adalah negara yang memiliki bermacam-macam suku, budaya, agama, ras, golongan. Tentunya kita sebagai masyarakat Indonesia harus ada rasa saling menghormati dan menghargai antar sesama warga negara walaupun dalam kenyataannya berbeda suku, ras, agama, golongan dan budaya. Sehingga terciptanya kerukunan antar umat beragama serta tidak mengakibatkan perpecahan bangsa Indonesia. Terutama bagi setiap orang dalam memeluk agama di Indonesia jangan sampai adanya Diskriminasi antar pemeluk agama dan golongan di negara ini. Jaminan kebebasan kehidupan beragama sebenarnya cukup kuat. Namun, keindahan aturan-aturan normatif tidak serta merta indah pula dalam kenyataannya. Masih banyak warga Negara Indonesia yang merasa dikekang kebebasannya dalam memeluk agama dan berkeyakinan.. Bahkan, orang yang mempunyai keyakinan tertentu, bisa dituduh melakukan penodaan agama. Jaminan kebebasan beragama pertama-tama dapat dilihat dari konstitusi atau Undang-Undang Dasar negara kita. Pasal 28 (e) ayat 1 dan 2 UUD 1945 hasil amandemen disebutkan: 1) "Setiap orang bebas memeluk agama dan beribadat menurut agamanya, memilih pendidikan dan pengajaran, memilih pekerjaan, memilih kewarganegaraan, memilih tempat tinggal di wilayah negara dan meninggalkannya, serta berhak kembali"; 2) "Setiap orang berhak atas kebebasan meyakini kepercayaan, menyatakan pikiran dan sikap, sesuai dengan hati nuraninya". Hal tersebut ditegaskan lagi dalam pasal 29 (1) "Negara 
berdasarkan Ketuhanan Yang Maha Esa.", (2) "Negara menjamin kemerdekaan tiaptiap penduduk untuk memeluk agamanya masing-masing dan untuk beribadat menurut agama dan kepercayaanya itu."

Dalam UU No. 39 Tahun 1999 tentang Hak Asasi Manusia memberikan landasan normatif bahwa agama dan keyakinan merupakan hak dasar yang tidak bisa diganggu gugat. Dalam pasal 22 ditegaskan: 1) Setiap orang bebas memeluk agamanya masing-masing dan untuk beribadat menurut agamanya dan kepercayaannya itu; 2) Negara menjamin kemerdekaan setiap orang memeluk agamanya masingmasing dan untuk beribadat menurut agamanya dan kepercayaannya itu". Dalam pasal 8 juga ditegaskan bahwa "Perlindungan, pemajuan, penegakan, dan pemenuhan hak asasi manusia menjadi tanggung jawab negara, terutama pemerintah".

Dari pasal tersebut jelas bahwa negara (pemerintah) adalah institusi yang pertamatama berkewajiban untuk menjamin kebebasan berkeyakinan dan segala sesuatu yang menjadi turunannya, seperti pengakuan hak-hak sipilnya tanpa diskriminasi. Dalam pasal 1c UU No. 39 Tahun 1999 dijelaskan bahwa "diskriminasi adalah setiap pembatasan, pelecehan, atau pengucilan yang langsung maupun tak langsung didasarkan pada pembedaan manusia atas dasar suku, ras, etnis, kelompok, golongan, status sosial, status ekonomi, jenis kelamin, bahasa, keyakinan politik yang berakibat pengurangan, penyimpangan, atau penghapusan pengakuan, pelaksanaan atau penggunaan hak asasi manusia dan kebebasan dasar dalam kehidupan baik individual maupun kolektif dalam bidang politik, ekonomi, hukum, sosial, budaya dan aspek kehidupan lainnya". Di samping itu, tuntutan untuk menjamin kebebasan beragama dan berkeyakinan juga menjadi tuntutan international sebagaimana tertuang dalam
International Covenant on Civil and Political Rights (ICPPR). Indonesia sudah meratifikasi tentang ICCPR melalui Undang-Undang No. 12 Tahun 2005 tentang Pengesahan International Covenant on Civil and Political Rights (Kovenan Internasional tentang HakHak Sipil dan Politik). Dengan ratifikasi itu, maka Indonesia menjadi Negara Pihak (State Parties) yang terikat dengan isi ICCPR. Kovenan menetapkan hak setiap orang atas kebebasan berpikir, berkeyakinan dan beragama serta perlindungan atas hak-hak tersebut (Pasal 18); hak orang untuk mempunyai pendapat tanpa campur tangan pihak lain dan hak atas kebebasan untuk menyatakan pendapat (Pasal 19); persamaan kedudukan semua orang di depan hukum dan hak semua orang atas perlindungan hukum yang sama tanpa diskriminasi (Pasal 26); dan tindakan untuk melindungi golongan etnis, agama, atau bahasa minoritas yang mungkin ada di negara pihak (Pasal 27).

ICCPR pada dasarnya memuat ketentuan mengenai pembatasan penggunaan kewenangan oleh aparat represif negara, khususnya aparatur represif Negara. Makanya hak-hak yang terhimpun di dalamnya juga sering disebut sebagai hak negatif (negative rights). Artinya, hak-hak dan kebebasan yang dijamin di dalamnya akan dapat terpenuhi apabila peran negara dibatasi. Apabila negara terlalu intervensi, hak-hak dan kebebasan yang diatur di dalamnya akan dilanggar oleh negara. Negara-negara Pihak yang melakukan pelanggaran terhadap hak-hak tersebut, akan mendapat kecaman sebagai negara yang telah melakukan pelanggaran serius hak asasi manusia (gross violation of human rights). Meski secara konstitusi jaminan atas kebebasan beragama dan berkeyakinan cukup kuat, namun pada tingkat implementasi masih sangat lemah. Bahkan ada kesan, paradigma dan perspektif pemerintah dalam melihat agama dan segala keragamannya tidak 
berubah. Keragaman masih dianggap sebagai ancaman daripada kekayaan. Watak negara yang ingin sepenuhnya menguasai segi-segi kehidupan dalam masyarakat, terutama keyakinan, sebagai ciri negara otoriter juga belum sepenuhnya hilang.

Dalam rangka memberikan perlindungan hukum atas adanya kepentingan hukum bagi setiap warga negara tersebut, maka ketentuan tentang delik penodaan terhadap agama harus diatur dalam RUU KUHP. Oleh karena itu perangkat peraturan perundang-undangan yang mengatur mengenai delik agama harus direkonstruksi dan di reevaluasi kembali sehingga delik agama dapat ditangani secara profesional dan proporsional oleh aparat penegak hukum. Dengan demikian negara Indonesia yang multi agama, multi etnik dan multi ras dapat terhindar dari hal-hal menghancurkan khususnya konflik-konflik antar umat beragama. Dengan demikian sifat perjuangan dalam mewujudkan tegaknya HAM di Indonesia itu tidak bisa dilihat sebagai pertentangan yang hanya mewakili kepentingan suatu golongan tertentu saja, melaikan menyangkut kepentingan bangsa Indonesia secara utuh. $^{1}$

Bertitik tolak dari pemikiran di atas, maka penulis tertarik untuk melakukan penulisan skripsi dengan judul: "Delik Penodaan Agama di Tinjau Dari Sudut Pandang Hukum Pidana di Indonesia", dimana akan dikemukakan perumusan dalam perundang-undangan hukum pidana terkait dengan penodaan terhadap agama.

\section{B. PERUMUSAN MASALAH}

1. Bagaimanakah perumusan ketentuan delik penodaan terhadap agama

\footnotetext{
1 Bambang Sutiyoso., Reformasi Keadilan dan Penegakan Hukum di Indonesia, UII Press, Yogyakarta, 2010,hal 173.
}

menurut Kitab Undang-Undang Hukum Pidana?

2. Bagaimanakah penerapan delik penodaan terhadap agama dalam praktek perdilan?

\section{METODE PENELITIAN}

Penelitian hukum normatif merupakan penelitian yang dilakukan dengan cara meneliti bahan pustaka. Menurut Soerjono Soekanto dan Sri Mamuji, penelitian hukum normatif mencakup: (1) penelitian terhadap asas-asas hukum; (2) penelitian terhadap sistematik hukum; (3) penelitian terhadap taraf sinkronisasi vertikal dan horizontal; (4) perbandingan hukum; dan (5) sejarah hukum. $^{2}$

\section{HASIL PEMBAHASAN}

\section{Delik Penodaan Terhadap Agama Dalam Perumusan Ketentuan Kitab Undang - Undang Hukum Pidana.}

Dalam KUHP (WvS) sebenarnya tidak ada bab khusus mengenai delik agama, meski ada beberapa delik yang sebenarnya dapat dikategorikan sebagai delik agama. Istilah delik agama itu sendiri sebenarnya mengandung beberapa pengertian: a) delik menurut agama; b) delik terhadap agama; c) delik yang berhubungan dengan agama. Adami Chazawi mengemukakan mengenai kejahatan penghinaan yang berhubungan dengan agama ini, dapat dibedakan menjadi 4 (empat) macam, ialah: 1) Penghinaan terhadap agama tertentu yang ada di Indonesia (Pasal 156a). 2) Penghinaan terhadap petugas agama yang menjalankan tugasnya (Pasal 177) angka 1). 3) Penghinaan mengenai benda-benda untuk keperluan ibadah (Pasal 177 angka 2). 4) Menimbulkan gaduh di dekat tempat

\footnotetext{
2 Soerjono Soekanto dan Sri Mamuji, Penelitian Hukum Normatif "Suatu Tinjauan Singkat", Rajawali Pers, Jakarta, 1990, hal. 15.
} 
Ibadah yang sedang digunakan beribadah (Pasal 503). ${ }^{1}$

Bila dicermati sebenarnya delik menurut agama bukan tidak ada dalam KUHP meski hal itu tidak secara penuh ada dalam KUHP seperti delik pembunuhan, pencurian, penipuan/perbuatan curang, penghinaan, fitnah, delik-delik kesusilaan (zina, perkosaan dan sebagainya).

Sedangkan pasal 156a yang sering disebut dengan pasal penodaan agama bisa dikategorikan sebagai delik terhadap agama. Sedang delik kategori c tersebar dalam beberapa perbuatan seperti merintangi pertemuan/upacara agama dan upacara penguburan jenazah (pasal 175); mengganggu pertemuan /upacara agama dan upacara penguburan jenazah (pasal 176); menertawakan petugas agama dalam menjalankan tugasnya yang diizinkan dan sebagainya. Bagian ini akan lebih difokuskan pada pasal 156a yang sering dijadikan rujukan hakim untuk memutus kasus penodaan agama. Pasal ini selengkapnya berbunyi: "Dipidana dengan pidana penjara selama-lamanya lima tahun barang siapa dengan sengaja di muka umum mengeluarkan perasaan atau melakukan perbuatan: a. yang pokoknya bersifat permusuhan, penyalahgunaan atau penodaan terhadap suatu agama yang dianut di Indonesia; $b$. dengan maksud agar supaya orang tidak menganut agama apapun juga, yang bersendikan Ketuhanan Yang maha Esa." Sebagaimana telah disinggung, pasal ini bisa dikategorikan sebagai delik terhadap agama. Asumsinya, yang ingin dilindungi oleh pasal ini adalah agama itu sendiri. Agama, menurut pasal ini, perlu dilindungi dari kemungkinankemungkinan perbuatan orang yang bisa merendahkan dan menistakan simbolsimbol agama seperti Tuhan, Nabi, Kitab Suci dan sebagainya. Meski demikian,

1 Adami H Cahzawi., Hukum Pidana Positif Penghinaan, Penerbit PMN, Surbaya, 2009, hal 237. karena agama "tidak bisa bicara" maka sebenarnya pasal ini juga ditujukan untuk melindungi penganut agama.

Pasal tersebut masuk dalam Bab V KUHP tentang Kejahatan terhadap Ketertiban Umum. Di sini tidak ada tindak pidana yang secara spesifik mengatur tindak pidana terhadap agama. Pasal 156a merupakan tambahan untuk men-stressing-kan tindak pidana terhadap agama. Dalam pasal 156 disebutkan: Barang siapa di muka umum menyatakan perasaan permusuhan, kebencian, atau penghinaan terhadap suatu atau beberapa golongan rakyat Indonesia, diancam dengan pidana penjara paling lama empat tahun atau pidana denda paling banyak empat ribu lima ratus rupiah. Perkataan golongan dalam pasal ini dan pasal berikutnya berarti tiap-tiap bagian dari rakyat Indonesia yang berbeda dengan suatu atau beberapa bagian lainnya karena ras, negeri asal, agama, tempat asal, keturunan, kebangsaan atau kedudukan menurut hukum tata negara.

Perlu dijelaskan bahwa pasal 156a tidak berasal dari Wetboek van Strafrecht (WvS) Belanda, melainkan dari UU No. 1/PNPS/1965 (LN 1965 No 3), dan ditempatkan dalam Pasal 156a, yang rumusan lengkapnya adalah: Dipidana dengan pidana penjara selama-lamanya lima tahun barangsiapa dengan sengaja di muka umum mengeluarkan perasaan atau melakukan perbuatan:

a. yang pada pokoknya bersifat permusuhan, penyalahgunaan atau penodaan terhadap suatu agama yang dianut di Indonesia;

b. dengan maksud agar supaya orang tidak menganut agama apapun juga, yang bersendikan Ketuhanan Yang Maha Esa. $^{2}$

Benih-benih delik penodaan agama juga dapat dilihat dalam pasal 1 Undang-Undang No. 1/PNPS/1965 tegas menyebutkan

\footnotetext{
${ }^{2}$ Ibid, hal 238
} 
larangan mengusahakan dukungan umum dan untuk melakukan penafsiran tentang sesuatu agama. Ketentuan pasal ini selengkapnya berbunyi: "Setiap orang dilarang dengan sengaja di muka umum menceritakan, menganjurkan atau mengusahakan dukungan umum untuk melakukan penafsiran tentang sesuatu agama yang utama di Indonesia atau melakukan kegiatan-kegiatan keagamaan yang menyerupai kegiatan-kegiatan agama itu, penafsiran dan kegiatan mana menyimpang dari pokok-pokok ajaran dari agama itu". Pasal 156a ini dimasukkan ke dalam KUHP Bab $\mathrm{V}$ tentang Kejatahan terhadap Ketertiban Umum yang mengatur perbuatan menyatakan perasaan permusuhan, kebencian atau penghinaan terhadap orang atau golongan lain di depan umum. Juga terhadap orang atau golongan yang berlainan suku, agama, keturunan dan sebagainya. Pasal-pasal tersebut tampaknya merupakan penjabaran dari prinsip anti-diskriminasi dan untuk melindungi minoritas dari kewenangwenangan kelompok mayoritas. Mengapa aturan tentang penodaan agama perlu dimasukkan dalam KUHP? Pertanyaan ini barangkali bisa dijawab dengan memperhatikan konsideran dalam UU No. 1/PNPS/1965 tersebut. Di sana disebutkan beberapa hal, antara lain: pertama, undang-undang ini dibuat untuk mengamankan Negara dan masyarakat, cita-cita revolusi dan pembangunan nasional dimana penyalahgunaan atau penodaan agama dipandang sebagai ancaman revolusi. Kedua, timbulnya berbagai aliran-aliran atau organisasiorganisasi kebatinan/kepercayaan masyarakat yang dianggap bertentangan dengan ajaran dan hukum agama. Aliranaliran tersebut dipandang telah melanggar hukum, memecah persatuan nasional dan menodai agama, sehingga perlu kewaspadaan nasional dengan mengeluarkan undang-undang ini. Ketiga, karena itu, aturan ini dimaksudkan untuk mencegah agar jangan sampai terjadi penyelewengan ajaran-ajaran agama yang dianggap sebagai ajaran-ajaran pokok oleh para ulama dari agama yang bersangkutan; dan aturan ini melindungi ketenteraman beragama tersebut dari penodaan/penghinaan serta dari ajaranajaran untuk tidak memeluk agama yang bersendikan Ketuhanan Yang Maha Esa. Keempat, seraya menyebut enam agama yang diakui pemerintah (Islam, Kristen, Katolik, Hindu, Budha dan Khong $\mathrm{Hu} \mathrm{Cu}$, undang-undang ini berupaya sedemikian rupa agar aliran-aliran keagamaan di luar enam agama tersebut dibatasi kehadirannya.

Dasar yang digunakan untuk memasukkan delik agama dalam KUHP adalah sila Ketuhanan Yang Maha Esa sebagai causa prima negara Pancasila. UUD 1945 pasal 29 juga menyebutkan bahwa negara berdasarkan atas Ketuhana Yang Maha Esa. Karena itu, kalau ada orang yang mengejek dan penodaan Tuhan yang disembah tidak dapat dibiarkan tanpa pemidanaan. Atas dasar itu, dengan meilihat Ketuhanan Yang Maha Esa sebagai titik sentral dari kehidupan kenegaraan, maka delik Godslastering sebagai blasphemy menjadi prioritas dalam delik agama.

Memasukkan kejahatan penodaan terhadap agama, pada dasarnya berlatar belakang pada usaha preventif secara dini agar tidak terjadi pertentangan yang lebih tajam antar umat beragama yang dapat mengakibatkan perpecahan bangsa Indonesia, dan membahayakan keutuhan bangasa Indonesia.

Upaya penanggulangan delik agama di Indonesia pada saat ini di Indonesia masih menggunakan KUHP (WvS). Pilihan untuk menggunakan KUHP untuk melakukan penanggulangan terhadap delik agama tersebut merupakan langkah kebijakan 
yang tidak bisa dilepaskan dari lingkup yang lebih besar yaitu kebijakan sosial.

Hukum pidana Indonesia sebagai sistem hukum yang merupakan adopsi dari hukum Belanda dalam menetapkan perbuatan pidana atau tercelanya suatu perbuatan adalah menggunakan Pasal 1 ayat (1) KUHP. Perumusan dalam pasal 1 ayat (1) yang dikenal dengan asas legalitas, merupakan tolok ukur dalam menentukan atau mengetahui secara pasti dan jelas, perbuatan yang dilarang dan diancam dengan pidana. Dengan adanya ketentuan tersebut maka, barangsiapa yang terbukti melanggar ketentuan yang ada dalam peraturan perundang-undangan atau dengan kata lain telah memenuhi semua unsur yang telah tercantum dalam undangundang pidana maka secara formal perbuatan tersebut merupakan perbuatan pidana.

Dimasukkannya delik agama dalam kelompok kejahatan yang mengganggu ketertiban umum tersebut karena delik agama secara umum dinilai bertentangan atau melanggar membahayakan kepentingan umum/masyarakat. Singkatnya kejahatan terhadap agama adalah kejahatan terhadap ketertiban umum. Pada awalnya, KUHP yang sekarang masih berlaku tidak mengatur delik agama. Delik agama dalam KUHP muncul setelah terbit Undang-undang No.1/PNPS/1965. Pasal 4 undang-undang tersebut memerintahkan agar ketentuan pasal undang-undang tersebut yang mengatur tentang delik agama dimasukkan dalam KUHP khususnya Pasal 156 a KUHP. Dengan dimasukkannya Pasal 156 a KUHP tersebut merupakan langkah kebijakan untuk memberikan perlindungan terhadap kepentingan hukum khususnya rasa keagamaan seseorang. Ditinjau dari segi materi ataupun pelaksanaannya Pasal 156 KUHP menghendaki perlindungan terhadap "golongan penduduk", atau dengan kata lain; pasal ini menghendaki perlindungan terhadap "orang", baik orang itu termasuk dalam "golongan" yang diakui sah menurut undang-undang negara, maupun karena golongan menurut "agamanya". Objek yang dilindungi adalah "orang", yang dilindunginya adalah bukan fisiknya, tetapi rasa kehormatan diri orang itu.

\section{B. Delik Penodaan Terhadap Agama Dalam Praktek Peradilan}

Dalam pelaksanaan proses peradilan terhadap delik agama ini,agar dapat berjalan secara efektif haruslah senantiasa di atur secara rinci dalam hukum pidana nasional. Guna setiap orang yang merasa di rugikan mendapat kepastian hukum dan merasakan adanya perlindungan hukum bagi mereka. Ada kecenderungan, kebijakan pemerintah dalam masalah agama senantiasa menimbulkan prokontra. Hal ini karena kelompok-kelompok agama di Indonesia mempunyai aspirasi yang bukan saja berbeda, tapi saling bertentangan. Karena itu, kelompokkelompok agama cenderung ramai-ramai meminjam "tangan negara" untuk memperjuangkan dan mengamankan posisinya. Kecenderungan ini tampak kian jelas bila kita mengikuti pro-kontra sejumlah regulasi di bidang praktek peradilan.Idealnya memang demikian, namun persoalannya adalah bagaimana mungkin dapat menghasilkan peradilan yang cepat sementara prosedur yang ada sekarang tidak mendung peradilan yang cepat tersenut. ${ }^{8}$ Dengan "mengamankan" agenda keagamaan melalui pasal dalam undang-undang dan regulasi lainnya, maka tindakan yang diskriminatif sekalipun bisa menjadi "kebenaran" karena disahkan oleh undang-undang. Kondisi ini jelas berbahaya, karena undang-undang bisa menjadi sandera untuk membenarnya tindakan yang melanggar konstitusi

\footnotetext{
8 Rusli Muhammad., Sistem Peradilan Pidana Indonesia, UII Press, Yogyakarta, 2011, hal 172.
} 
sekalipun. Tanggung jawab kepada masyarakat diharapkan lembaga peradilan akan memperoleh kepercayaan dari masyarakat. ${ }^{9}$ Salah satu fungsi penting hukum pidana adalah untuk memberikan dasar legitimasi bagi tindakan represif negara terhadap seseorang atau kelompok orang yang melakukan perbuatan yang mengancam dan membahayakan, serta merugikan kepentingan umum.

\section{Kasus Cerpen "Langit Makin Mendung" karya ki Pandji Kusmin}

Sejauh riset yang dilakukan di sini, merupakan kasus penodaan agama pertama setelah pasal 156a dimasukkan dalam KUHP. Korbannya adalah Hans Bague Jassin (HB Jassin) yang divonis telah melakukan penodaan agama dengan hukuman satu tahun penjara dengan masa percobaan dua tahun. Masalah itu bermula dari terbitknya cerpen berjudul Langit Makin Mendung (LMM) karya Ki Pandji Kusmin yang dimuat di majalah Sastra edisi 8 Agustus 1968. Cerpen itu menimbulkan kecaman dari berbagai pihak, terutama umat Islam. Akibat rekasi massa yang semakin kuat, Kejaksaan Tinggi Sumatera Utara melarang peredaran majalah Sastra yang memuat cerpen tersebut karena isinya dianggap menghina kesucian agama Islam. Akibatnya ratusan eksemplar majalah Sastra disita di berbagai toko, agen dan pengecer di kota Medan. Bukan itu saja, protes massa terus berlanjut dengan demonstrasi ke kantor majalah Sastra. Sekitar 50 pemuda berunjuk rasa dari mulai orasi sampai aksi coret-coret dinding kantor dengan segala macam penghinaan. Nuansa sindrom komunisme begitu kuat dalam tulisan-tulisan demonstran seperti H.B Jassin Kunjuk! (Kunyuk, ejaan lama-red), H.B Jassin Tangan Kotor Gestapu PKI, Ini Kantor Lekra, Majalah Sastra: Anti Islam, dan lain-lain. Akibat demonstasi tersebut

\footnotetext{
${ }^{9}$ Ibid, hal 185
}

majalah Sastra kemudian ditutup sampai batas waktu yang ditentukan. Kalangan sastrawan pun bereaksi. Di Medan sejumlah sastrawan terkemuka seperti Sori Siregar, Zakaria M. Passe dan Rusli A. Malem membuat pernyataan protes. Di Jakarta tak ketinggalan Umar Kayam, Taufiq Ismail, Trisno Sumarjdo, D. Djajakusuma dan Slamet Soekirnanto ikut menandatangani pernyataan protes. Nama Ki Pandjikusmin sendiri 'mencuat' sehingga dipelesetkan menjadi "Kibarkan PandjiPandji Komunis Internasional" . Polemik terus berkelanjutan. Setahun sesudah itu tajuk rencana harian Indonesia Raja menulis : "Ki Pandji Kusmin, Tampillah Engkau Sekarang Sebagai Ksatria."

H.B Jassin selaku redaktur majalah Sastra diseret ke pengadilan. Akan tetapi di muka pengadilan ia berkeras tidak mengungkap identitas $\mathrm{Ki}$ Pandji Kusmin dengan berpegang pada UU Pers 1966: "bila sang pengarang tidak membuka identitasnya redaksi mempunyai hak tolak memberitahukan identitas pengarang sesungguhnya." Cerpen ini juga berbuntut panjang dan menyebabkan polemik sastra meributkan soal fantasi, kebebasan mencipta dan agama. Polemik tersebut berkepanjangan hingga dua tahun lamanya. Di pengadilan H.B Jassin mengaku selama ini hanya berhubungan lewat surat. la juga mengatakan sang pengarang berprofesi sebagai pelaut. Alamatnya selalu berpindah-pindah. Spekulasi bermunculan. Bahkan ada yang berasumsi H.B Jassin sendirilah Ki Pandji Kusmin itu.

Ki Pandji Kusmin sendiri bukannya tidak tinggal diam. Pengarang misterius ini lewat redaksi Harian Kami tertanggal 22 Oktober 1968 mengeluarkan pernyataan mencabut cerpennya dan menganggapnya tak pernah ada. Berikut pernyataannya:

"Sebermula sekali bukan maksud saya menghina agama Islam. Tujuan sebenarnya adalah semata-mata hasrat pribadi saya mengadakan komunikasi langsung dengan 
Tuhan, Nabi Muhammad S.A.W, sorga. dll. Di samping menertawakan kebodohan di masa rezim Soekarno. Tapi rupanya saya telah gagal, salah menuangkannya ke dalam bentuk cerpen. Alhasil mendapat tanggapan di kalangan umat Islam sebagai penghinaan terhadap agama Islam." Kisah ini belakangan diterbitkan dalam buku berjudul "Pledoi Satra: Kontroversi Cerpen Langit Makin Mendung Ki Pandji Kusmin" tahun 2004. Berikut ini dilampirkan cerpen dimaksud dan juga resensi buku Pledoi Sastra.

\section{Kasus Sekte Pondok Nabi}

Kasus ini terjadi di lingkungan agama Protestan. Korbanya adalah Mangapin Sibuea, 59 tahun, pimpinan sekte 'Pondok Nabi' di Bandung. Mangapin Sibuea dijatuhi hukuman dua tahun penjara dengan tuduhan melanggar pasal 156a KUHP tentang tindak pidana bersifat permusuhan, penyalahgunaan atau penodaan terhadap suatu agama yang dianut di Indonesia oleh Pengadilan Negeri Bale Endah, Bandung, Jawa Barat. ${ }^{10}$ Vonis penjara dengan potongan masa tahanan itu dibacakan Ketua Majelis Hakim Sir Johan, didampingi hakim anggota, Dwi Sugiarto dan DS Dewi, Selasa 6/4/2004. Selain vonis penjara, hakim memutuskan bahwa barang bukti berupa tiga keping VCD berisi rekaman khotbah Mangapin dan sebuah buku berjudul 'Kiamat Dunia Akan Segera Terjadi' disita (Kompas Cyber Media, 7 April 2004). Sebanyak 283 anggota jemaat sekte yang sedang menunggu kiamat di rumah peribadatan mereka dipimpin pendeta Mangapin Sibuea di Jalan Siliwangi, Bale Endah, Kabupaten Bandung, Senin (10/11/03). Namun, mereka kemudian dievakuasi aparat Kepolisian Resor Bandung. Ini dilakukan menyusul protes warga sekitarnya. Selain itu, ada kekhawatiran para anggota jemaat yang di

\footnotetext{
${ }^{10}$ www.tempointeraktif.com, 8 April 2004
}

dalamnya banyak anak-anak akan melakukan upaya bunuh diri. Sebelumnya, suasana di Bale Endah pada petang hari menjelang pukul 15.00 memang kurang kondusif, dengan berkumpulnya puluhan warga masyarakat yang umumnya keberatan tentang adanya aktivitas jemaat di sekitar lingkungan mereka itu. Dari dalam rumah ibadah Pondok Nabi yang berlantai dua itu sendiri terdengar nyanyian dan tangis jemaat. Pada pukul 15.30, aparat Bimbingan Masyarakat Polres Bandung memutuskan mengevakuasi jemaat Pondok Nabi ke Gereja Bethel Tabernakel di Jalan Lengkong Besar, Bandung, dengan menggunakan mobil pengendalian massa (dalmas). Evakuasi ke gereja itu atas petunjuk Dewan Gereja Jawa Barat, agar jemaat itu bisa dibina kembali.

Jemaat Pondok Nabi tersebut dievakuasi dengan didampingi Tim Crisis Center Forum Komunikasi Kristen (TCC FKK) Jawa Barat. Acara pengangkatan dengan berkumpul di Pondok Nabi, memang gagal. Tapi dia mengelak kalau pengangkatan urung terjadi, lantaran aparat polisi dan pihak Crisis Center Forum Komunikasi Kristen Indonesia (FKKI) menghentikan acara tersebut. "Ditengah-tengah acara Pendeta Simon Timorason masuk," kata Sibuea. Pendeta Simon Timorason adalah Ketua Crisis Center FKKI Jawa Barat. FKKI tergolong menentang dan menganggap Sibuea sesat (www.tempointeraktif.com, 12 November 2003).

Sibuea kemudian diperiksa dan ditahan. 13 tersangka yang lain juga diperiksa selama dua hari lalu ditahan di Markas Polres Bandung. Mereka adalah Michael Timotius, Ester Sinaga, Andreas, Ferry, Charles, Brijones, Marthen, Josep Hasian, Ery Indiardi, Yohanes, Daniel Kale, Yani Batuwael, dan Sela. Mereka juga masih menjalani pemeriksaan. Sebelas dari mereka bertindak sebagai rasul dan seorang selaku nabiah (nabi perempuan). Sedangkan 21 pengurus sekte kiamat 
pimpinan pendeta Mangapin Sibuea lain hingga kini masih diperiksa intensif. Mereka semua perempuan dan 14 di antaranya adalah nabiah. ${ }^{11}$

Pada proses berikutnya, Mangapin yang diduga menyebarkan aliran sesat kepada para jemaatnya, dituntut tiga tahun penjara oleh Jaksa Penuntut Umum (JPU) Hutagaol, $\mathrm{SH}$., dalam sidang pembacaan tuntutan di PN Bale Bandung. Sidang dipimpin majelis hakim yang diketuai Sir Johan, $\mathrm{SH}$ dengan dua anggotanya Eddy Pangaribuan, SH., serta Bachtiar Sitompul, SH. la dituntut telah melakukan tidak pidana penodaan agama secara berulang kali sebagaimana diatur dalam pasal 156a KUHP. Penodaan agama tersebut dilakukan terdakwa sekitar Mei 2002-Januari 2003 lalu di tempat tinggalnya di RT 02 RW.08, Kel. Baleendah Kec. Baleendah, Kab. Bandung. Sibuea dengan sengaja di muka umum melakukan perbuatan bersifat permusuhan, penyalahgunaan atau penodaan agama yang dianut di Indonesia.

Yang dianggap lebih menyesatkan lagi, Mangapin meyakini bahwa pada 10 November 2003 dunia akan kiamat. la meyakini hal itu melalui suara langsung yang didengar dari Tuhan ke telinganya setelahnya berpuasa selama tujuh hari tujuh malam. Di bulan Mei 2002, Mangapin telah merekam ajarannya dalam sebuah VCD kemudian disampaikan kepada para jemaatnya. Dalam rekaman itu terdakwa mengatakan bahwa pendeta-pendeta Kristen adalah nabi-nabi palsu yang tempatnya di neraka dan menyebutkan baptisan di luar kebenaran al-Kitab.

Sumber yang dihimpun di lapangan menyebutkan, ratusan warga yang meluapkan kekesalan mereka terhadap Mangapin itu terjadi secara mendadak. "Mereka datang satu per satu, lalu tidak lama kemudian menjadi kumpulan massa. Kejadiannya tidak lama, kurang dari

\footnotetext{
${ }^{11}$ www.liputan6.com, 12/11/2003.
}

seperempat jam," tutur Erma, warga yang rumahnya berdampingan dengan 'Pondok Nabi'. Pada proses selanjutnya, pihak Mangapin menuntut balik. Menurut Habel Rumbiak, sang pengacara, tindakan FKKI dianggap telah mendeskriditkan banyak pihak di kelompok pondok nabi, pribadi dan keluarga Managapin. Dugaan adanya unsur fitnah pun ditujukan kepada Simon dan FKKI dalam tiap pernyataannya. Secara organisasi, FKKI akan dituntut secara perdata. "Untuk tuntutan yang satu lagi, kita akan mengajukan pasal 310, 311 tentang pasal penghinaan KUHP pidana," kata Habel. Menanggapi itu, Pendeta Simon mengaku tidak gentar. Karena apa yang dilakukannya adalah gerakan kemanusiaan. "Bayangkan, kalau waktu itu mereka bunuh diri massal?," kata Simon. Ketidak-gentaran Simon ditunjukkannya dengan dukungan pengacara dari Persatuan Gereja Indonesia Wilayah (PGIW) Jawa Barat, Gerakan Angkatan Muda Kristen (Gamki) dan lainnya. Simon juga membantah dirinya melakukan penghinaan terhadap Mangapin. Karena apa yang dilakukan FKKI adalah mengevakuasi. "FKKI khawatir massa stress, lalu terjadi bunuh diri atau mati massal," kata Simon. Simon justru menyesalkan sikap pengacara yang hanya memikirkan Sibuea. "Pikirkan dong nasib ratusan jemaatnya," katanya. Dicontohkannya, para jemaat kesulitan biaya untuk pulang kampung, lantaran harta benda sudah dijual demi Mangapin. ${ }^{12}$

Sekte pimpinannya ini sebenarnya telah dilarang Kantor Wilayah Departemen Agama Jawa Barat pada tahun 2000. Pondok Nabi dinyatakan sebagai aliran sesat. Tim Reserse Kriminal Kepolisian Resor Bandung Tengah menetapkan 13 dari 34 pengurus sekte kiamat sebagai tersangka. Mereka bakal dijerat Pasal 156a KUHP tentang permusuhan,

${ }^{12}$ www.tempointeraktif.com, 20 November 2003 
penyalahgunaan atau penodaan agama dengan ancaman penjara lima tahun.

\section{F. PENUTUP}

\section{Kesimpulan}

1. Perumusan ketentuan delik penodaan terhadap agama dalam Kitab UndangUndang Hukum Pidana (KUHP) dimasukkan dalam kelompok kejahatan penghinaan, karena penodaan disini mengandung sifat penghinaan, melecehkan, meremehkan dari suatu agama. Karena itu menyakitkan perasaan bagi umat pemeluk agama yang bersangkutan, sehingga unsur hal ini memenuhi unsur yang ada dalam ketentuan Pasal 156a KUHPidana yang terdiri dari: (1) Melakukan perbuatan mengeluarkan perasaan dan melakukan perbuatan, dan (2) di muka umum.

2. Dalam praktek peradilan terkait dengan delik penodaan terhadap agama yang sering menjadi kesulitan dalah Istilah penodaan terhadap agama sesungguhnya sangat abstrak sehingga bisa digunakan oleh kelompok tertentu, terutama kelompok mainstream yang menuduh kelompok lain telah menodai agama dengan keyakinan dan praktik agamanya. Dalam praktiknya pasal tentang penodaan agama menjadi pasal yang sangat lentur yang bisa dipahami secara sepihak.

\section{B. Saran}

Berdasarkan hasil penelitian yang telah dikemukakan di atas, maka penulis memberikan beberapa saran sebagai berikut :

1. Dalam upaya penanggulangan delik agama hendaknya memperhatikan karakteristik delik agama sebagai kejahatan yang menyangkut kepentingan masyarakat luas yang sangat berperan dalam kehidupan berbangsa dan bernegara haruslah diatur secara rinci dalam ketentuan hukum pidana nasional;

2. Upaya penanggulangan delik terhadap agama ini dapat berjalan secara efektif dengan sarana proses peradilan yang adil dan memberikan kepastian hukum bagi setiap pencari keadilan agar semua dapat merasakan ada perlindungan hukum bagi mereka yang merasa dirugikan.

\section{DAFTAR PUSTAKA}

Abdurrahman Wahid, Aspek Religius Agama-Agama di Indonesia dan Pembangunan, dalam Masyur Amin, edt. Moralitas Pembangunan Perspektif Agama-Agama di Indonesia, Yogyakarta: KPSM-NU, 1989.

Adami H Cahzawi., Hukum Pidana Positif Penghinaan, Penerbit PMN, Surbaya, 2009.

Bambang Sutiyoso., Reformasi Keadilan dan Penegakan Hukum di Indonesia, UII Press, Yogyakarta, 2010.

Franz Magnis Suseno, Kuasa dan Moral, Jakarta: Gramedia, 1986

Juhaya S Pradja dan Ahmad Syihabuddin, Delik Agama dalam Hukum Pidana di Indonesia, Bandung: Angkasa, 2000.

Hary Susanto, Memeluk Agama, Menemukan Kebebasan, dalam I Wibowo dan B Herry Priyono (edt), Sesudah Filsafat: Esai-Esai Untuk Franz Magnis Suseno, Yogyakarta: Kanisius, 2006.

Hendro Puspito, Sosiologi Agama, Yoyakarta: Kanisius, 1989.

Koentjaraninggrat, Aneka Warna Manusia dan Kebudayaan Indonesia Dalam Pembangunandalam Koentjaraninggrat, Manusia dan Kebudayaan Di Indonesia, Jakarta: Djambatan, 1999.

Oemar Seno Adji, Hukum Pidana Pengembangan, cet. I, Jakarta: Erlangga, 1985. 
Oemar Seno Adji, Herziening, Ganti Rugi, Suap, Perkembangan Delik, Jakarta: Erlangga, 1981,

PAF Lamintang., Kitab Pelajaran Hukum Pidana, Cetakan Pertama, Bandung: Pionir Jaya, 1992.

Peter Mahmud Marzuki, Penelitian hukum, Jakarta: Prenada Media, 2005.

Ronny Hanitijo Soemitro, Metodelogi Penelitian Hukum dan Jurimetri, Jakarta: Ghalia Indonesia, 1990.

Rusli Muhamm., Sistem Peradilan Pidana Indonesia, UII Press, Yogyakarta, 2011.

Seno Herbangan Siagian, Pengantar Agama Kristen, Semarang: Satya Wacana, 1985.

Sidjabat, Penelitian Agama: Pendekatana Dari Ilmu Agama, dalam Mulyanto Sumadi, edt. Penelitian Agama: Masalah dan Pemikiran, Jakarta: Sinar Harapan, 1982.

Soerjono Soekanto, Pengantar Penelitian hukum, Jakarta, UI PRESS, 1986.

Soerjono Soekanto dan Sri Mamudji, Penelitian Hukum Normatif Rajawali Pers, Jakarta, 1990.

Sudiarja, Menantikan Kiprah Kaum Berjubah, dalam A Sudiarja dan A Bagus Laksana (edt), erenang di Arus Zaman: Tantangan Hidup Religius di Indonesia Kini, Yogyakarta: Kanisius, 2003.

Zakiah Derajat, IImu Jiwa Agama, Bulan Bintang, Jakarta, 1973. 